\title{
USE OF FAT TAIL DIMENSIONS FOR PREDICTION OF FAT IN TAIL AND CARCASS IN EGYPTIAN RAM LAMBS
}

\author{
Rania Agamy*, A.Y. Abdel-Moneim, M.S. Abd-Alla, I.I. Abdel-Mageed and G.M. Ashmawi \\ Department of Animal Production, Faculty of Agriculture, Cairo University, Giza, Egypt \\ * Corresponding author Email: (rania.agamy@agr.cu.edu.eg)
}

\section{SUMMARY}

Forty five Egyptian ram lambs, 15 of each of Ossimi, Barki and Rahmani were used to investigate the influence of breed and body weight on fat tail measurements and carcass composition. Fat tail measurements were also used to establish prediction equations to predict weights of fat tail (FTW), dissected carcass fat and total body fat (TBF). Fat tail measurements were upper (UFTT) and lower (LFTT) tail thickness, upper (UFTW) and lower (LFTW) tail width, upper (UFTC) and lower (LFTC) tail circumference as well as tail length (FTL). Body weight $(B W)$, Empty body weight $(E B W)$, hot carcass weight $(H C W)$, fat tail weight $(F T W)$, pericardial fat weight, omental fat weight, mesenteric fat weight and perinephric and pelvic fat weight were also recorded. The left half carcasses were dissected into conventional cuts. Barki ram lambs had significantly $(P<0.01)$ the least all fat tail dimensions. Ossimi ram lambs had significantly $(P<0.01)$ the highest LFTW, UFTC and LFTC. However, $\mathrm{HCW}$ was significantly $(P<0.05)$ the highest in Ossimi ram lambs $(21.3 \mathrm{~kg})$ followed by Rahmani (20.5 kg) and Barki ones (20.2 kg). The highest dressing percentage was that of Ossimi carcass (52.0\%) which was significantly $(P<0.05)$ more than those of Rahmani $(50.1 \%)$ and Barki $(49.3 \%)$ carcasses. Carcass of Ossimi significantly $(P<0.05)$ excelled that of Barki and Rahmani breeds in total fat stores. Carcasses of Barki ram lambs had significantly $(P<0.05)$ higher non-carcass fat and dissected carcass fat and lower fat tail weight as a percentage of total body fat than that of both Ossimi and Rahmani. FTW was positively and highly significant $(P<0.01)$ correlated with UFTC in Rahmani ram lambs $(r=0.93)$ and Barki ones $(r=0.89)$. However, LFTC was positively and highly significant $(P<0.01)$ correlated with FTW in Ossimi ram lambs $(r=0.95)$. It was found that positive and significant correlation coefficients were obtained between FTW of all breeds studied and TBF and dissected carcass fat. Moreover, the upper circumference of tail accounted for $79 \%$ and $86 \%$ of the total variation in tail weight of Barki and Rahmani ram lambs, respectively. In Ossimi, both lower circumference and thickness of fat tail accounted for $94 \%$ of the total variation in FTW. The obtained results cast light on the fat tail dimensions as the accurate parameters for prediction of fat weight in carcass of Egyptian sheep.

Keywords: Ossimi, Barki, Rahmani, prediction, fat tail measurements, fat tail, total body fat, carcass fat.

\section{INTRODUCTION}

Animal fat is still an important element in the diets of people living in many tropical regions of the world (Ermias and Rege, 2003). Fat-tailed breeds represent the dominance of sheep breeds throughout the drier regions of Africa, Middle East and Asia (Ben Hamouda and Atti, 2011). The main sheep breeds in Egypt are Ossimi, Rahmani and Barki. Fattail weight is a major adipose depot component of total body weight in fat-tail sheep. The fat-tail plays an important role in adaptation of sheep raised under the harsh feeding conditions of arid and semi-arid regions, where the availability of foodstuffs, especially good quality roughage, is seasonal (Vatankhah and Talebi, 2008). It is desirable to use in vivo methods to evaluate fat and carcass composition and be applicable in young animals, enabling early selection of lambs with highly desirable carcass composition as breeding stock. Subjective assessments of fat and carcasses composition were carried out by different techniques. It is possible to assess fattening as well as growth of animals by linear measurements, ultrasound, X-ray computed tomography (CT) and nuclear magnetic resonance (NMR).

The relationship between fat-tail weight and dimensions in Egyptian sheep has not yet been studied. To obtain reliable estimates of genetic and phenotypic parameters in fat tail breeds of sheep, the relationship between fat tail weight and meat production traits should be determined.

The objectives of the present work were: a) to study the influence of breed and body weight of ram lamb on in vivo fat-tail dimensions and carcass traits of the three major breeds of Egyptian sheep (Ossimi, Barki and Rahmani) and b) To predict fat weight of tail, carcass and whole body from in vivo tail measurements. The relationship between fat-tail weight and measurements and carcass traits were also examined.

\section{MATERIAL AND METHODS}

\section{Animals}


A total of 45 Egyptian ram lambs, 15 of each of Ossimi, Barki and Rahmani fat-tail breeds, were used in this study. Animals belonged to the Small Ruminants Station, Faculty of Agriculture, Cairo University, Giza, Egypt. Lambs were reared with their dams for four months post-lambing (suckling period). Then, they were kept free in semi-shaded open yards $(5 \mathrm{~m} \times 8 \mathrm{~m})$ with a $1.6 \mathrm{~m}$ high fence. Lambs were fed in groups according to their live body weight (NRC requirements, 1985) on concentrate feed mixture (consisted of $55 \%$ yellow corn, $20 \%$ wheat bran, $10 \%$ cottonseed cake, $10 \%$ soybean cake, $2 \%$ limestone, $1.5 \%$ common slate, $1 \%$ minerals mixture and $0.5 \%$ sodium bicarbonate). In addition, lambs were fed on Egyptian clover (Trifolium alexandrinum), Darawa (Zea maize L.) or Egyptian clover hay according to their availability. Drinking water and mineral blocks were made available all the daytime.

\section{Experimental procedure and data collection}

\section{In vivo measurements}

Body weight and fat-tail measurements were recorded before slaughter at 12 months of age (slaughter age). Ram lambs were fasted for 18 hours before taking these measurements. According to several investigators (Zamiri and Izadifard, 1997; Atti and Ben Hamouda, 2004; Safdarian et al., 2008; Ben Hamouda and Atti, 2011) seven linear dimensions of fat tail had been individually measured on shorn fat tail. These dimensions were upper fattail circumference (UFTC), lower fat-tail circumference (LFTC), upper fat-tail thickness (UFTT), lower fat-tail thickness (LFTT), upper fattail width (UFTW), lower fat-tail width (LFTW) and fat-tail length (FTL). Upper and lower refer to measurements taken, respectively, at the base and the widest part of the fat-tail. Tail length measurement included only the fat part and not the thin part of tail on middle inner side of the tail, the distance between the base of tail close to the body and the tip of the tail. Circumference, width and length were measured using a flexible measuring tape in centimeter to the nearest $0.5 \mathrm{~cm}$, whereas, caliper was used to measure thickness. Body weight was measured using a $0.1 \mathrm{~kg}$ precision scale in kilograms. All measurements were made while the animal was hold in a standing position. In order to avoid intra-individual variations, all measurements were taken by the same person.

\section{Carcass evaluation}

All ram lambs were slaughtered at the experimental abattoir of Faculty of Agriculture, Cairo University, Giza, Egypt, after 18 h of fasting. Pre-slaughtering body weight was taken just before slaughtering. This weight was taken as the slaughter weight on which the calculation of dressing percentage was based. The ram lambs were slaughtered according to the Muslim (halal) tradition by severing the throat and major blood vessels in the neck at the allanto-occipital joint. After bleeding, body was weighed, and the carcass was skinned and head and feet were removed. The carcass was decapitated and internal offals (heart, lung and trachea, liver, kidney, spleen and testis) were removed. The fat deposited around the kidneys (pelvis and perinephric fat), heart (pericardial fat) and fat around the gastrointestinal tract (omental and mesenteric fat) were dissected and weighed. Weights of pericardial, omental, mesenteric and perinephric and pelvic fats were taken as the total non-carcass fat (TNCF). Total fat stores (TFS) included total noncarcass fat and fat tail weight. The digestive tract was removed and weighed with and without contents. The content was then determined as the difference. Digestive tract content weight was subtracted from body weight to obtain empty body weight (EBW). Hot carcass including the fat-tail, were weighed within one hour after slaughtering. The fat-tail was removed from hot carcass and weighed (FTW). Volume of tail was carefully determined by measuring the volume of displaced water after immersion in water. The carcass was split along the median plane into approximately two equal halves, left and right sides, using a band saw and each half was weighed. After cooling for 24 hours at $4^{\circ} \mathrm{C}$, twenty two (7 Barki, 8 Ossimi and 7 Rahmani) of left side of carcasses were divided into conventional cuts including leg, shoulder, lumbar region, thoracic region, neck and flank (Abdel-Moneim, 2009). Each cut was weighed then completely dissected into bone, dissected fat (subcutaneous and intermuscular) and trimmed meat (including the nerves and connective tissue) which was weighed separately. Total body fat (TBF) included total fat store and total carcass dissected fat from various cuts. Composition of whole carcasses was estimated from the composition of the dissected side as follows as suggested by Awgichew (2000): Total trimmed meat $=$ constant $\times$ weight of trimmed meat from left carcass, Total dissected fat $=$ constant $\times$ weight of dissected fat from left carcass, Total bone $=$ constant $\times$ weight of bone from left carcass, Constant = carcass (whole) without fat tail weight / left half carcass weight.

\section{Chemical analysis}

Meat chemical analysis was performed using Food Scan TM Pro meat analyzer (Foss Analytical A/S, Model 78810, Denmark) in the Research Park, Faculty of Agriculture, Cairo University. According to the manufacturer's instruction about 50-100 gm of meat (obtained from Longissimus dorsi muscle at the $11^{\text {th }}-13^{\text {th }}$ ribs) were minced and put in the meat analyzer cup. The cup was inserted into the meat analyzer for scanning sample with infra-red to determine the chemical components (ether extract, protein, moisture and collagen $\%$ ). 


\section{Statistical analysis}

Data were analysed by least squares procedure of General Linear Model (GLM) using SAS statistical package (SAS, 2004). Data of fat tail weight and measurements and carcass characteristics were analyzed using the following model:

Where:

$Y_{i j}=\mu+g_{i}+b\left(x_{i j}-\bar{X}_{i j}\right)+e_{i j}$

$\mathrm{Y}_{\mathrm{ij}}=$ Experimental observation,

$\mu=$ Overall mean,

$\mathrm{g}_{\mathrm{i}}=$ Fixed effect of breed ( $\mathrm{i}=1$ : Barki, 2: Ossimi and

3: Rahmani),

$\mathrm{b}=$ Partial linear regression of the dependent variable $\mathrm{Y}$ on body weight of ram lamb,

$\mathrm{x}_{\mathrm{ij}}=$ The independent continuous variable for body weight of ram lamb,

$\overline{\mathrm{X}}_{\mathrm{ij}}=$ The mean of body weight of ram lamb,

$\mathrm{e}_{\mathrm{ij}}=$ Random error and was assumed as NID $\left(0, \sigma_{\mathrm{e}}{ }^{2}\right)$ Significant differences among means were detected using Duncan's Multiple Range Test.

Simple correlation coefficients between fat tail weight and dimensions, fat content and carcass characteristics, within each breed, were calculated and tested for significance. For each breed, to predict fat tail weight, carcass fat and total body fat based on fat tail measurements, the stepwise procedure was used to select the variable for prediction equations. This procedure did not include variables with a $\mathrm{P}>$ 0.05 as suggested by Diaz et al. (2004) and Marshall et al. (2005). However, in Barki sheep all fat tail measurements did not reach the significant level of 0.05 of prediction of both dissected carcass fat and total body fat. The coefficient of determination $\mathrm{R}^{2}$ assessed the accuracy of the equations.

\section{RESULTS AND DISCUSSION}

\section{The effect of breed and body weight on fat tail dimensions}

It appears from Table (1) that breed of ram lamb exerted a highly significant $(\mathrm{P}<0.01)$ effect on all fattail dimensions studied. Barki ram lambs had significantly $(\mathrm{P}<0.05)$ the lowest values of the all tail measurements compared with Ossimi and Rahmani ones. Meanwhile, LFTW, UFTC and LFTC were significantly $(\mathrm{P}<0.01)$ higher in Ossimi ram lamb than in Rahmani ones (Table 1). Whereas, FTL, UFTW, UFTT and LFTT did not significantly differ between Ossimi and Rahmani ram lambs (Table 1).

On the other hand, the partial linear regression coefficients of all fat tail measurements were positive and highly significant $(\mathrm{P}<0.01)$ except fat tail length which was significant at $(\mathrm{P}<0.05)($ Table 1$)$. These results are in harmony with those previously reported by Safdarian et al. (2008) and Vatankhah and Talebi (2008). Safdarian et al. (2008) concluded that fat tail dimensions generally increased as body weight increased. Vatankhah and Talebi (2008) found positive and significant genetic correlation among body weight of lambs and various fat-tail measurements.

The obtained results (Table 1) showed that tail shape was different in the three breeds. It appears to be square shaped in Ossimi and triangular in Barki. Generally, the tail in the three breeds was broader in the medium than at the level of its junction with the abdomen. It was 16.7 and $13.9 \mathrm{~cm}$ in Barki, 24.0 and $18.4 \mathrm{~cm}$ in Ossimi and 20.8 and $17.7 \mathrm{~cm}$ in Rahmani, respectively (Table 1). Similar observations were found in Mehraban and Ghezel breeds, where the width at the base and at the middle of tail was 23.0 and $29.0 \mathrm{~cm}$, respectively (Zamiri and Izadifard, 1997). Atti and Ben Hamouda (2004) found that width of tail of Barbarine breed was $20.0 \mathrm{~cm}$ and $26.0 \mathrm{~cm}$ at the base and the middle of tail, respectively.

\section{The effect of breed and body weight on carcass characteristics}

Breed had no effect on empty body weight, hot carcass weight without fat tail and dressing percentage based on hot carcass without fat tail (Table 2). Whereas, hot carcass weight included fat tail and dressing percentage based on hot carcass weight with fat tail were affected significantly ( $\mathrm{P}<$ 0.05 ) by breed (Table 2). It is interesting to observe that the significantly $(\mathrm{P}<0.05)$ heaviest hot carcass weight and dressing percentage of Ossimi might be attributed to heaviest fat tail weight $(2.58 \mathrm{~kg})$ (Table 2).

Similar significant differences in carcass weight and dressing percentage of sheep were observed by Galal et al. (1975), Hassan et al. (1996), Burke and Apple (2007) and Abdel-Moneim (2009). Galal et al. (1975) found that carcass weight of Barki yearling rams was the lightest among the breeding groups (Merino, Awassi and their crosses). Whereas, Ossimi lambs had the highest carcass weight compared with Chios and crossbred (Hassan et al., 1996). AbdelMoneim (2009) found that Ossimi ram lambs produce heavier $(\mathrm{P}<0.05)$ hot carcass weight than carcasses of Rahmani and dressing percentage was significantly $(\mathrm{P}<0.05)$ higher in Ossimi ram lambs than in Barki and Rahmani.

On the contrary, El-Asheeri et al. (2006) and Pérez et al. (2007) reported that breed of lamb had no significant effect on dressing percentage. El-Asheeri et al. (2006) noticed that the dressing percentage was approximately similar for Rahmani (49.1\%) and Ossimi $(49.8 \%)$ ram lambs. It is interesting that the obtained dressing percentages are similar to those already reported for lambs of the Egyptian breeds (48.8 to 51.1\%) for 12 months old Ossimi lambs (Hassan and E1-Feel, 1991 and El Asheeri et al., 2006) and (44.8 to $49.1 \%$ ) for 12 months Rahmani lambs (Awadalla et al., 1997 and E1 Asheeri et al., 2006). But higher dressing percentage (53 and $57 \%$ ) was reported by Mowafy (1968) and Galal et al. (1975) for Barki lambs (12 months) and for Ossimi, 
Barki and Rahmani lambs (12 months) by AbdelMoneim (2009).

It is apparent from the results in Table 2 that the partial linear regression coefficients of each of empty body weight and hot carcass weight on body weight of ram lamb were positive and highly significant $(\mathrm{P}<0.01)$. This means that we can depend on live weight of the native breed when selecting for higher carcass weight. This finding is supported by the findings of Ermias and Rege (2003) who found that live weight had strong positive genetic and phenotypic correlations with hot and cold carcass weight in Menz and Horro sheep. Similarly, AbdelMoneim (2009) showed that carcass weights can be significantly increased by using sires that are genetically superior in weight.

Table 1. Least square mean $(\bar{X})$, standard error and regression coefficient values of in vivo fat tail dimensions (cm) at slaughter as affected by breed and body weight of Egyptian fat tailed ram lambs

\begin{tabular}{|c|c|c|c|c|c|c|c|c|c|}
\hline \multirow{2}{*}{ Tail dimensions } & \multicolumn{2}{|c|}{ Barki } & \multicolumn{2}{|c|}{ Ossimi } & \multicolumn{2}{|c|}{ Rahmani } & \multirow[t]{2}{*}{ Sig. } & \multicolumn{2}{|c|}{$\begin{array}{c}\text { Reg. on body } \\
\text { weight (Kg) }\end{array}$} \\
\hline & $\overline{\mathrm{X}}$ & S.E. & $\overline{\mathrm{X}}$ & S.E. & $\overline{\mathrm{X}}$ & S.E. & & $\mathbf{b}$ & S.E. \\
\hline Length (FTL) & $17.6 \mathrm{~b}$ & 0.75 & $21.6 \mathrm{a}$ & 0.81 & $22.0 \mathrm{a}$ & 0.70 & $* *$ & $0.16^{*}$ & 0.07 \\
\hline Upper width (UFTW) & $13.9 \mathrm{~b}$ & 0.49 & $18.4 \mathrm{a}$ & 0.53 & $17.7 \mathrm{a}$ & 0.45 & $* *$ & $0.20 * *$ & 0.04 \\
\hline Lower width (LFTW) & $16.7 \mathrm{c}$ & 0.56 & $24.0 \mathrm{a}$ & 0.60 & $20.8 b$ & 0.52 & $* *$ & $0.28 * *$ & 0.05 \\
\hline Upper circumference (UFTC) & $32.2 \mathrm{c}$ & 1.16 & $42.8 \mathrm{a}$ & 1.26 & $37.6 \mathrm{~b}$ & 1.08 & $* *$ & $0.57 * *$ & 0.10 \\
\hline Lower circumference (LFTC) & $31.8 \mathrm{c}$ & 1.53 & $48.7 \mathrm{a}$ & 1.66 & $42.5 b$ & 1.43 & $* *$ & $0.59 * *$ & 0.14 \\
\hline Upper thickness (UFTT) & $5.1 b$ & 0.33 & $6.8 \mathrm{a}$ & 0.35 & $6.3 \mathrm{a}$ & 0.31 & $* *$ & $0.10 * *$ & 0.03 \\
\hline Lower thickness (LFTT) & $4.6 \mathrm{~b}$ & 0.19 & $6.1 \mathrm{a}$ & 0.20 & $5.6 \mathrm{a}$ & 0.18 & $* *$ & $0.10 * *$ & 0.02 \\
\hline
\end{tabular}

Within breeds, means of each trait not followed by the same letter differ significantly from each other $(\mathrm{P}<0.05)$.

Sig. significance, $* \mathrm{P}<0.05$, ** $\mathrm{P}<0.01$, S.E.: Standard error.

Table 2. Least square mean $(\bar{X})$, standard error and regression coefficient values of carcass composition as affected by breed and body weight of Egyptian fat tailed ram lambs

\begin{tabular}{|c|c|c|c|c|c|c|c|c|c|}
\hline \multirow{2}{*}{ Carcass composition } & \multicolumn{2}{|c|}{ Barki } & \multicolumn{2}{|c|}{ Ossimi } & \multicolumn{2}{|c|}{ Rahmani } & \multirow[t]{2}{*}{ Sig. } & \multicolumn{2}{|c|}{$\begin{array}{c}\text { Reg. on body } \\
\text { weight (Kg) }\end{array}$} \\
\hline & $\overline{\mathrm{X}}$ & S.E. & $\overline{\mathrm{X}}$ & S.E. & $\overline{\mathrm{X}}$ & S.E. & & $\mathbf{b}$ & S.E. \\
\hline Empty body weight, kg & $34.1 \mathrm{a}$ & 0.25 & $34.8 \mathrm{a}$ & 0.29 & $34.4 \mathrm{a}$ & 0.24 & ns & $0.85 * *$ & 0.02 \\
\hline Hot carcass weight + tail, $\mathbf{k g}$ & $20.2 b$ & 0.26 & $21.3 \mathrm{a}$ & 0.27 & $20.5 b$ & 0.23 & $*$ & $0.56 * *$ & 0.02 \\
\hline Hot carcass weight - tail, kg & $19.0 \mathrm{a}$ & 0.30 & $18.7 \mathrm{a}$ & 0.32 & $18.5 \mathrm{a}$ & 0.28 & ns & $0.47 * *$ & 0.03 \\
\hline Dressing (+ tail) \% & $49.3 b$ & 0.65 & $52.0 \mathrm{a}$ & 0.67 & $50.1 b$ & 0.59 & $*$ & $0.12 *$ & 0.06 \\
\hline Dressing (- tail) \% & $46.7 \mathrm{a}$ & 0.71 & $46.0 \mathrm{a}$ & 0.74 & $45.3 \mathrm{a}$ & 0.65 & ns & 0.04 & 0.06 \\
\hline \multicolumn{10}{|l|}{ Carcass composition, $\mathrm{kg}$} \\
\hline Bone, kg & $3.7 \mathrm{a}$ & 0.12 & $3.7 \mathrm{a}$ & 0.11 & $3.9 \mathrm{a}$ & 0.11 & ns & $0.08 * *$ & 0.02 \\
\hline Trimmed meat, kg & $12.8 \mathrm{a}$ & 0.49 & $11.6 \mathrm{a}$ & 0.46 & $12.5 \mathrm{a}$ & 0.43 & ns & $0.37 * *$ & 0.06 \\
\hline Dissected fat, kg & $3.3 \mathrm{a}$ & 0.30 & $3.5 \mathrm{a}$ & 0.28 & $2.4 \mathrm{~b}$ & 0.26 & $*$ & $0.11^{* *}$ & 0.04 \\
\hline Fat tail weight, $\mathrm{kg}$ & $1.2 \mathrm{c}$ & 0.17 & $2.6 \mathrm{a}$ & 0.19 & $2.0 \mathrm{~b}$ & 0.16 & $* *$ & $0.09 * *$ & 0.02 \\
\hline \multicolumn{10}{|l|}{ Carcass composition, \% } \\
\hline Bone, \% & $17.8 \mathrm{a}$ & 0.61 & $17.3 \mathrm{a}$ & 0.58 & $18.8 \mathrm{a}$ & 0.54 & ns & $-0.19 *$ & 0.08 \\
\hline Trimmed meat, \% & $61.0 \mathrm{a}$ & 1.79 & $54.9 \mathrm{~b}$ & 1.68 & $60.1 \mathrm{a}$ & 1.57 & & 0.02 & 0.23 \\
\hline Dissected fat, \% & $15.7 \mathrm{a}$ & 1.20 & $15.9 \mathrm{a}$ & 1.13 & $11.5 b$ & 1.05 & $*$ & 0.12 & 0.16 \\
\hline Fat tail, \% & $5.3 b$ & 0.72 & $11.4 \mathrm{a}$ & 0.76 & $9.6 \mathrm{a}$ & 0.66 & $* *$ & $0.16^{*}$ & 0.06 \\
\hline Lean/fat ratio & $4.1 b$ & 0.45 & $3.5 b$ & 0.42 & $5.5 \mathrm{a}$ & 0.39 & $* *$ & -0.003 & 0.06 \\
\hline Lean/bone ratio & $3.4 \mathrm{a}$ & 0.14 & $3.2 \mathrm{a}$ & 0.13 & $3.2 \mathrm{a}$ & 0.12 & $\mathrm{~ns}$ & 0.03 & 0.02 \\
\hline
\end{tabular}

Dressing \%: hot carcass weight as a proportion of slaughter weight

Within breeds, means of each trait not followed by the same letter differ significantly from each other $(\mathrm{P}<0.05)$.

Sig. significance, $* \mathrm{P}<0.05, * * \mathrm{P}<0.01$, S.E.: Standard error. 
On the other side, a positive and significant $(\mathrm{P}<$ $0.05)$ regression coefficient of dressing percentage on body weight of ram lamb was found. Different results were reported by Seker and Kul (2001) who found that the phenotypic correlation coefficient between body weight and dressing percentage was positive but non-significant. Also, Abdel-Moneim (2009) found positive and non-significant regression coefficient of dressing percentage on body weight of ram lambs.

On the other hand, no significant differences in either bone or trimmed meat weight of whole carcass were found among the three breeds (Table 2). Dissected carcass fat weight of Rahmani ram lambs $(2.4 \mathrm{~kg})$ was significantly $(\mathrm{P}<0.05)$ lighter than that of Barki (3.3 kg) and Ossimi (3.5 kg). Fat tail weight was least for Barki $(1.2 \mathrm{~kg})$, medium for Rahmani $(2.0 \mathrm{~kg})$ and highest for Ossimi $(2.6 \mathrm{~kg})$, differences were highly significant $(\mathrm{P}<0.01)$.

Carcass composition expressed as percentage of carcass weight (Table 2) revealed that in all breeds, trimmed meat had the highest percentage, followed respectively by bone percentage, dissected carcass fat while fat tail represented the least percentage. It is interesting that bone percentage did not differ significantly among breeds. It is generally accepted that Rahmani sheep has the biggest skeleton among Egyptian breeds. Trimmed meat percentage was significantly least for Ossimi lambs (54.9\%) and nearly similar for Barki and Rahmani $(61.0 \%$ and $60.1 \%$, respectively) (Table 2). The results may be attributed to the comparative larger carcass dissected fat and tail fat of the Ossimi than that of Rahmani sheep. As reported by Berg and Walters (1983), the proportion of lean in a carcass varies indirectly with fat proportion whereby a higher fat proportion is associated with a lower proportion of muscle and vice versa. Dissected carcass fat percentage in Rahmani (11.5\%) was significantly less than that of either Barki or Ossimi $(15.7 \%$ and $15.9 \%$, respectively) (Table 2). It is generally known that Rahmani breed have the largest body frame and body weight, so it is considered late maturing compared with Ossimi and Barki breeds. Consequently, Rahmani lambs are expected to possess less fat than other breeds when all are slaughtered at the same age. It is known that, bone tissue matures early followed by muscle and fat tissue maturing later. Orr (1982) stated that animals of the same species often vary in their mature body size and weight which is also reflected in the differences of their carcass composition. Berg and Walters (1983) observed genetical differences in fat deposition among breeds due to different growth capacity and maturity. In this respect, El-Shahat et al. (1986) found that carcasses of Rahmani lambs were fatter than those of Ossimi ones. Similar percentages of carcass composition were given by Kadak (1983) on Akkaraman lambs and El Karim and Owen (1987) on Sudan Desert sheep. Kadak (1983) recorded muscle, fat and bone percentage of Akkaraman lambs (42 kg) to be 58.5\%, $18.4 \%$ and $19.0 \%$, respectively. El Karim and Owen (1987) reported a carcass composition percentage of lean (58.1-59.2\%), fat (14.2-15.8\%) and bone (18.9$19.9 \%$ ) in Shugor and Watish lambs, respectively. Yardimc et al. (2008) found that composition of Akkaraman carcass was $48.9 \%$ muscle, $15.1 \%$ fat and $19.6 \%$ bone.

Percentage of fat tail was highest in Ossimi (11.4\%), medium in Rahmani (9.6\%) and significantly least in Barki $(5.3 \%)$ (Table 2). Fat tail percentage of some fat tail breeds were already, given, 15\% for Turkish Awassi (Ozcan et al., 1994), $6.3 \%$ for Barbarine breed (Atti and Ben Hamouda, 2004), $15.3 \%$ for Akkaraman lambs (Yardimc et al., 2008).

It appears from Table 2 that breed of ram lambs exerted a highly significant $(\mathrm{P}<0.01)$ effect on lean/fat ratio. Lean/fat ratio was significantly ( $P$ $<0.05)$ high in Rahmani lambs (5.5) than either Barki (4.1) or Ossimi (3.5) (Table 2). Lean/bone ratio was nearly similar for the three breeds studied (Table 2). Such results finding support a general idea that a traditional preference of Rahmani lambs as a good quality mutton. The results disagree with the finding of Awgichew (2000) who concluded that breed of Menz and Horro lambs had significant $(\mathrm{P}<0.05)$ effect on lean/bone ratio and non-significant effect on lean/fat ratio. Awgichew (2000) showed that lean/fat ratio for Menz and Horro lamb carcasses were (3.1 and 3.3, respectively) and lean/bone ratio were (2.9 and 2.7 , respectively).

It is shown in Table (2) that there were positive and highly significant $(\mathrm{P}<0.01)$ regression coefficients of bone, trimmed meat, dissected carcass fat and fat tail weight on body weight of ram lambs. Whereas, a negative and significant $(\mathrm{P}<0.05)$ regression coefficients of bone percentage on body weight of ram lambs was found (Table 2). The attained results indicate that increase in body weight is accompanied with increase in weight of carcass tissues and decrease in bone proportion relative to carcass weight. This result is supported by the findings of Ruvuna et al. 1992 and Safdarian et al. (2008). Ruvuna et al. (1992) showed that proportion of lean and fat increase with age while the proportion of bone decreases.

Chemical analysis of meat indicated that breed had highly significant $(\mathrm{P}<0.01)$ effect on moisture and fat percentage while it's effect was nonsignificant on protein and collagen contents. Similar results were reported by Ali (2007) who found that breed had no significant effect on protein content. Rahmani had significantly $(\mathrm{P}<0.05)$ lower meat fat percentage and higher moisture percentage than Ossimi and Barki (Fig. 1). This finding conforms to that of Ali (2007) who concluded that Ossimi breed had significantly $(\mathrm{P}<0.0001)$ higher fat percentage and lower $(\mathrm{P}<0.01)$ moisture percentage of carcass meat compared to Rahmani breed. 


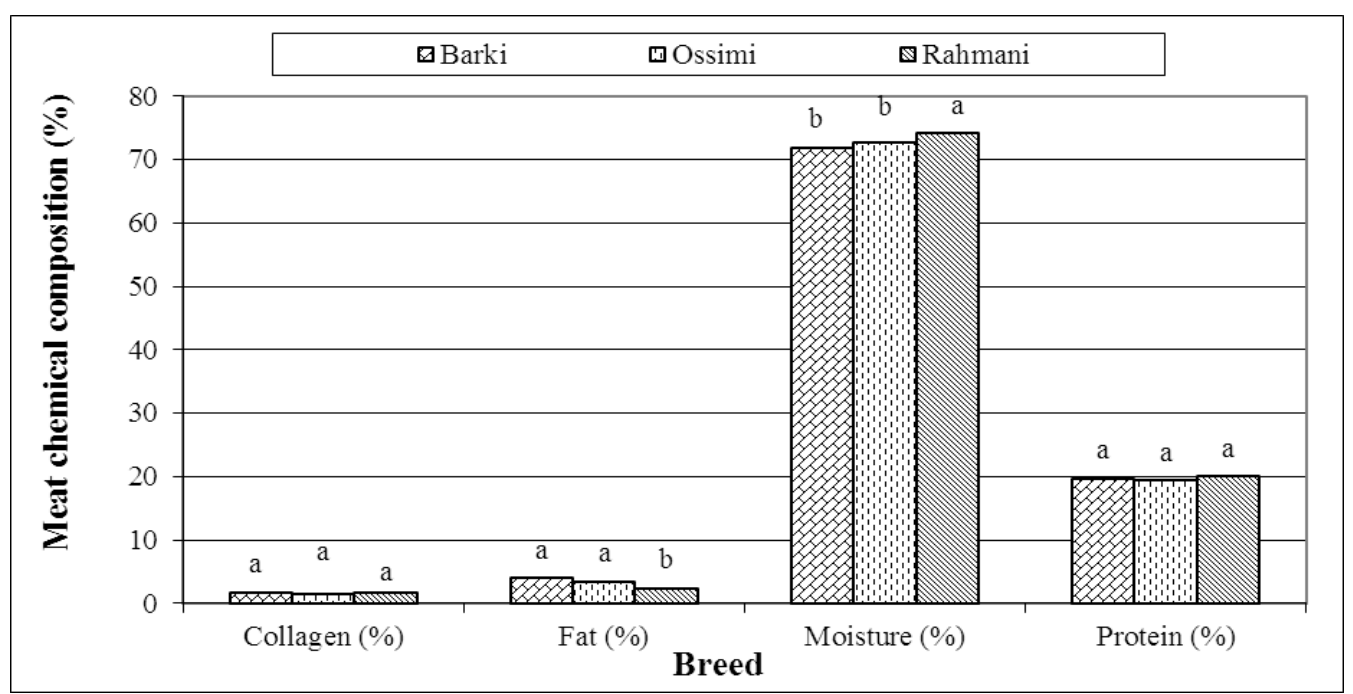

Fig. 1. Meat chemical composition of Barki, Ossimi and Rahmani ram lambs

\section{Effect of breed and body weight on total body fat}

No significant effect of breed on dissected fat weight of any carcass cut except that of the loin cut (Table 3). Dissected fat weight in loin cut of Rahmani carcass was significantly $(\mathrm{P}<0.05)$ lower than those of Barki and Ossimi (Table 3). Other workers, Zamiri and Izadifard (1997) reported that shoulder and back dissected fat was greater in carcasses of Mehraban rams compared to Ghezel ones. It is worthy to note that the regression coefficients of dissected fat weight of loin and thoracic region cuts on body weight were positive and significant $(\mathrm{P}<0.05)$ (Table 3$)$. These results may be interpreted in that fat proportion in any carcass cuts may increase with slaughter weight.

On the other hand, fat weight of heart, kidney and pelvic, omental as well as non-carcass fat weight in Barki significantly $(\mathrm{P}<0.05)$ exceeded that in Rahmani (Table 3). Meanwhile, differences among all these parameters in Ossimi were not significant likewise those of Barki and Rahmani. At the meantime, mesenteric fat weight did not differ among the three breeds (Table 3). Furthermore, the differences in fat tail volume among breeds were highly significant $(\mathrm{P}<0.01)$ (Table 3$)$. In this context, Ossimi ram lambs had significantly $(\mathrm{P}<0.05)$ the highest fat tail volume, followed by Rahmani carcass, whereas, Barki ram lambs had significantly $(\mathrm{P}<0.05)$ least fat tail volume in their carcasses.

Additionally, carcasses of Ossimi ram lambs had significantly $(\mathrm{P}<0.05)$ the highest total fat stores $(3.5$ $\mathrm{kg}$ ) than either Rahmani $(2.8 \mathrm{~kg}$ ) or Barki $(2.4 \mathrm{~kg})$. It is clear that the superiority of Ossimi in total fat stores was mainly due to its excessive fat tail than Rahmani and Barki (Table 3). In this context, total body fat weight of Ossimi was significantly $(\mathrm{P}<0.05)$ higher than of Rahmani, whereas total body fat weight of Barki did not significantly differ from that of both Ossimi and Rahmani (Table 3). Comparable result was reported by Atti and Ben Hamouda (2004) who found that weight of tail fat in Barbarine lambs was positively correlated with total body fat $(\mathrm{r}=$ $0.91, \mathrm{P}<0.01)$. Similar situation was observed by Abdel-Moneim (2009) who reported that carcass of Ossimi significantly $(\mathrm{P}<0.05)$ excelled that of Barki and Rahmani breeds in total fat stores $(4.2 \mathrm{~kg}, v s .2 .2$ and $2.9 \mathrm{~kg}$, respectively).

It is shown in Table (3) that there were positive and highly significant $(\mathrm{P}<0.01)$ regression coefficients of fat weight of heart, omental, mesenteric as well as non-carcass fat, fat tail volume, total fat store and total body fat on body weight of ram lambs. There was positive but insignificant regression coefficient of kidney and pelvic fat on body weight of ram lamb. Similar results were given by Abdel-Moneim (2009) in the three Egyptian breeds.

The results in Table (3) and Fig. (2) showed that breeds had fair difference in body fat distribution. However, carcasses of Barki ram lambs had significantly $(\mathrm{P}<0.05)$ higher total non-carcass fat and dissected carcass fat as well as lower fat tail weight as a percentage of total body fat than that of either Ossimi or Rahmani. Meanwhile, these of Ossimi carcass did not differ significantly from those of Rahmani carcass (Table 3). The present results indicate that Barki sheep which is a light tailed breed encourage fat deposition internally in their carcasses and round kidneys and guts not in the tail. Whereas, Ossimi and Rahmani sheep encourage fat deposition in tail, consequently the tail fat represented the largest proportion of the total dissectible fat. The obtained results conform with studies reported by Farid et al. (1983) and Abdel-Moneim (2009). Farid et al. (1983) stated that the fat stored in the tail contribute to the lower level of fat found elsewhere in various carcass cuts compared to non-fat tailed sheep breeds. Abdel-Moneim (2009) reported that Barki had significantly the highest non-carcass fat compared to Ossimi and Rahmani due to lighter fat tail. 
The relationships between fat tail weight and tail dimensions, body weight, and carcass characteristics of Egyptian ram lambs

It was noticed (Table 4) that fat tail weight of Barki ram lambs was positively and significantly ( $\mathrm{P}$ $<0.01)$ correlated with all fat tail dimensions except fat tail length (FTL). Meanwhile, positive and significant $(\mathrm{P}<0.01)$ correlation coefficients were found between fat tail weight of Ossimi ram lambs and each of UFTW, LFTW, UFTC, LFTC, LFTT, and significant $(\mathrm{P}<0.05)$ with FTL and UFTT (Table 4). However, all of fat tail dimensions of Rahmani ram lambs were positively and significantly $(\mathrm{P}<0.01)$ correlated with fat tail weight except UFTT which was significant $(\mathrm{P}<0.05)$ (Table 4$)$. Similar results were obtained by Atti and Ben Hamouda (2004) on Barbarian sheep and Safdarian et al. (2008) on Torki-Ghashghaii sheep. Atti and Ben Hamouda (2004) observed that all tail studied measurements were significantly and closely correlated to tail fat, carcass fat and total body fat. Safdarian et al. (2008) found that correlation coefficients of tail weight and dimension were large, positive and significant.

The highest correlation coefficients between fat tail weight and its dimensions were found between fat tail weight and UFTC $(\mathrm{r}=0.89 ; \mathrm{P}<0.01)$, LFTC $(\mathrm{r}=0.95 ; \mathrm{P}<0.01)$ and UFTC $(\mathrm{r}=0.93 ; \mathrm{P}<0.01)$ of Barki, Ossimi and Rahmani ram lambs, respectively (Table 4). This result is in agreement with that reported by Atti and Ben Hamouda (2004) who noticed that the highest correlation coefficients between fat tail weight and fat tail external measurements were 0.87 and 0.85 with UFTC and LFTC in Barbarine lambs, respectively. Similarly, Safdarian et al. (2008) found a correlation coefficient between fat tail weight and UFTC of 0.88 in TorkiGhashghaii ram lambs. It was 0.63 with LFTC in Makoei sheep (Farahani et al., 2010), 0.84 with LFTC in Ghezel rams (Zamiri and Izadifard, 1997) and 0.88 with LFTC in Akkaraman (Yardimici et al., 2008). Contrarily, highest correlation between fat-tail weight and fat tail measurements was between fat tail weight and LFTW ( $\mathrm{r}=0.87)$ in Mehraban (Zamiri and Izadifard, 1997).

Slaughter weight account for a large proportion of change in FTW in all of Barki $(r=0.77$; $\mathrm{P}<0.01)$, Ossimi ( $\mathrm{r}=0.66$; $\mathrm{P}<0.01)$ and Rahmani $(\mathrm{r}=0.80$; $\mathrm{P}<0.01$ ) ram lambs (Table 4). This result is in harmony with that obtained by Vatankhah and Talebi (2008) who found that positive and significant genetic correlation among body weight of lambs and various fat-tail measurements. Atti and Ben Hamouda (2004) showed that body weight of Barbarian lambs had a positive and significant correlation with fat tail weight $(\mathrm{r}=0.75)$. Meanwhile, Safdarian et al. (2008) showed that positive and significant correlation between body weight of
Torki-Ghashghaii ram lambs and FTW ( $\mathrm{r}=0.86, \mathrm{P}<$ 0.01). Similarly, it was 0.60 in Akkaraman (Yardimici et al., 2008) and 0.67 in Makoei (Farahani et al., 2010). Conversely, Zamiri and Izadifard (1997) concluded that slaughter weight accounted for a small proportion of the change in FTW in both Mehraban $(\mathrm{r}=0.47 ; \mathrm{P}<0.01)$ and Ghezel $(r=0.37 ; \mathrm{P}<0.05)$ rams. It was noticed that fat tail weight of each of Barki, Ossimi and Rahmani ram lambs were positively and significantly correlated with hot carcass weight (Table 4).

Results in Table (4) shows that trimmed meat relative to hot carcass weight of Ossimi ram lambs was negatively and significantly $(\mathrm{P}<0.01)$ associated with fat tail weight, but were insignificant in Barki and Rahmani carcasses. This finding coincided with that of Butler-Hogg et al. (1984) who reported that, carcass fatness, whether measured directly or estimated visually, was negatively correlated with saleable meat yield. It has been pointed out that increasing the lean yield was one way of increasing the commercial value of carcasses (Alkass et al., 1985 and Gokdal et al., 2003), since lean fetched a better market price than fat. Moreover, Zamiri and Izadifard (1997) reported that FTW was negatively correlated with trimmed meat $(r=-0.16$ and -0.15, in Mehraban and Ghezel rams, respectively). Similar observations were reported by Safdarian et al. (2008) in Torki-Ghashghaii ram lambs, where FTW was negatively correlated with trimmed meat $(\mathrm{r}=-0.64, \mathrm{P}<0.01)$.

It is apparent from the results in Table (4) that dissected carcass fat weight of Ossimi carcass was positively and significantly associated with FTW (P $<0.05)$, while it was positive and insignificant in both Barki and Rahmani. It is worthy to note that fat tail weight was positively and significantly $(\mathrm{P}<0.01)$ correlated with total fat store and positively but insignificant with total body fat in the three studied breeds (Table 4). This result agree with the finding of Zamiri and Izadifard (1997) who stated that correlation coefficient of fat tail weight with total carcass fat was significant in Mehraban $(r=0.75$; $\mathrm{P}<0.01)$ but not in Ghezel rams $(\mathrm{r}=0.27$; $\mathrm{P}>0.05)$. Atti and Ben Hamouda (2004) reported that weight of tail fat in Barbarine fat-tailed lambs was positively and significantly correlated with total body fat and total carcass fat $(\mathrm{r}=0.91$ and 0.93 , respectively). Safdarian et al. (2008) showed that FTW was positively and significantly $(\mathrm{P}<0.01)$ correlated with total carcass and total body fat $(\mathrm{r}=0.70$ and 0.81 , respectively) in Torki-Ghashghaii ram lambs. Similarly, Yardimici et al. (2008) indicated that fat tail weight was associated with total carcass fat $(\mathrm{r}=0.71)$ and total body fat $(\mathrm{r}=0.67)$ in Akkaraman lambs. Farahani et al. (2010) found that fat tail was correlated with abdominal fat weight $(r=0.43)$ in Makoei sheep. 
Table 3. Least square mean $(\overline{\mathrm{X}})$, standard error and regression coefficient values of body types fat as affected by breed and body weight of Egyptian fat tailed ram lambs.

\begin{tabular}{|c|c|c|c|c|c|c|c|c|c|}
\hline \multirow{2}{*}{ Fat type weight and percentage } & \multicolumn{2}{|c|}{ Barki } & \multicolumn{2}{|c|}{ Ossimi } & \multicolumn{2}{|c|}{ Rahmani } & \multirow[t]{2}{*}{ Sig. } & \multicolumn{2}{|c|}{$\begin{array}{c}\text { Reg. on body } \\
\text { weight (Kg) }\end{array}$} \\
\hline & $\overline{\mathrm{X}}$ & S.E. & $\overline{\mathrm{X}}$ & S.E. & $\overline{\mathrm{X}}$ & S.E. & & $\mathbf{b}$ & S.E. \\
\hline \multicolumn{10}{|c|}{ Dissected fat from cuts of half carcass } \\
\hline Flank, g & $155.4 \mathrm{a}$ & 20.96 & $143.3 \mathrm{a}$ & 19.67 & $114.4 \mathrm{a}$ & 18.33 & $\mathrm{~ns}$ & 5.04 & 2.72 \\
\hline Leg, $g$ & $244.1 \mathrm{a}$ & 37.82 & $267.9 \mathrm{a}$ & 35.49 & $174.0 \mathrm{a}$ & 33.08 & ns & 8.32 & 4.90 \\
\hline Neck, g & $94.6 \mathrm{a}$ & 14.26 & $105.1 \mathrm{a}$ & 13.38 & $68.8 \mathrm{a}$ & 12.47 & ns & 0.67 & 1.85 \\
\hline Loin, $\mathrm{g}$ & $398.5 \mathrm{a}$ & 35.91 & $415.4 \mathrm{a}$ & 33.70 & $233.3 b$ & 31.40 & $* *$ & $10.43 *$ & 4.65 \\
\hline Shoulder, g & $265.3 \mathrm{a}$ & 32.14 & $246.5 a$ & 30.16 & $182.2 \mathrm{a}$ & 28.10 & ns & 7.13 & 4.16 \\
\hline Thoracic region, $g$ & $416.9 a$ & 63.40 & $491.1 \mathrm{a}$ & 59.49 & $335.4 \mathrm{a}$ & 55.44 & ns & $17.74 *$ & 8.22 \\
\hline \multicolumn{10}{|l|}{ Internal organs fat } \\
\hline Heart, g & $66.4 \mathrm{a}$ & 4.47 & $54.9 \mathrm{ab}$ & 4.83 & $52.4 \mathrm{~b}$ & 4.17 & $*$ & $1.74 * *$ & 0.40 \\
\hline Kidney and pelvic, $\mathrm{g}$ & $212.3 \mathrm{a}$ & 23.74 & $170.2 \mathrm{ab}$ & 25.66 & $134.2 b$ & 22.14 & $*$ & 3.73 & 2.12 \\
\hline Omental, $\mathrm{g}$ & $503.6 \mathrm{a}$ & 49.77 & $370.8 \mathrm{ab}$ & 53.78 & $289.6 b$ & 46.41 & $* *$ & $14.67 * *$ & 4.45 \\
\hline Mesenteric, g & $421.0 \mathrm{a}$ & 32.20 & $365.4 \mathrm{a}$ & 34.80 & $387.6 \mathrm{a}$ & 30.03 & ns & $12.06 * *$ & 2.88 \\
\hline Total non-carcass fat, $\mathrm{kg}$ & $1.2 \mathrm{a}$ & 0.09 & $1.0 \mathrm{ab}$ & 0.09 & $0.9 b$ & 0.08 & $*$ & $0.03 * *$ & 0.01 \\
\hline Tail weight, kg & $1.2 \mathrm{c}$ & 0.17 & $2.6 a$ & 0.19 & $2.0 \mathrm{~b}$ & 0.16 & $* *$ & $0.09 * *$ & 0.02 \\
\hline Tail volume, 1 & $1.2 \mathrm{c}$ & 0.17 & $2.6 \mathrm{a}$ & 0.19 & $2.0 \mathrm{~b}$ & 0.16 & $* *$ & $0.09 * *$ & 0.02 \\
\hline Total fat store, $\mathrm{kg}$ & $2.4 \mathrm{~b}$ & 0.17 & $3.5 \mathrm{a}$ & 0.19 & $2.8 b$ & 0.16 & $* *$ & $0.12 * *$ & 0.02 \\
\hline Total body fat, $\mathrm{kg}$ & $5.8 \mathrm{ab}$ & 0.57 & $7.2 \mathrm{a}$ & 0.54 & $5.2 b$ & 0.50 & $*$ & $0.22 * *$ & 0.07 \\
\hline \multicolumn{10}{|l|}{ Body fat distribution } \\
\hline Total non-carcass fat, $\%^{1}$ & $22.6 \mathrm{a}$ & 2.17 & $14.8 \mathrm{~b}$ & 2.03 & $16.5 b$ & 1.90 & $*$ & 0.02 & 0.03 \\
\hline Fat tail, $\%^{1}$ & $20.0 \mathrm{~b}$ & 2.56 & $36.2 \mathrm{a}$ & 2.40 & $38.6 \mathrm{a}$ & 2.24 & $* *$ & -0.08 & 0.33 \\
\hline Dissected carcass fat, $\%^{1}$ & $57.4 \mathrm{a}$ & 1.77 & $49.0 \mathrm{~b}$ & 1.66 & $45.0 \mathrm{~b}$ & 1.55 & $* *$ & 0.06 & 0.23 \\
\hline
\end{tabular}

${ }^{1}$ Calculated as a percentage of total body fat

Within breeds, means of each trait not followed by the same letter differ significantly from each other $(\mathrm{P}<0.05)$.

Sig. significance, $* \mathrm{P}<0.05$, $* * \mathrm{P}<0.01$, S.E.: Standard error.

Table 4. Correlation coefficients between fat tail weight and tail dimensions and carcass characteristics of Barki, Ossimi and Rahmani ram lambs.

\begin{tabular}{lccc}
\hline Trait & Barki & Ossimi & Rahmani \\
\hline Fat tail length, cm & 0.08 & $0.60^{*}$ & $0.81^{* *}$ \\
Upper fat tail width, cm & $0.64^{* *}$ & $0.76^{* *}$ & $0.81^{* *}$ \\
Lower fat tail width, cm & $0.78^{* *}$ & $0.87^{* *}$ & $0.84^{* *}$ \\
Upper fat tail circumference, cm & $0.89^{* *}$ & $0.89^{* *}$ & $0.93^{* *}$ \\
Lower fat tail circumference, cm & $0.81^{* *}$ & $0.95^{* *}$ & $0.84^{* *}$ \\
Upper fat tail thickness, cm & $0.75^{* *}$ & $0.55^{*}$ & $0.63^{*}$ \\
Lower fat tail thickness, cm & $0.69^{* *}$ & $0.86^{* *}$ & $0.76^{* *}$ \\
Body weight, kg & $0.77^{* *}$ & $0.66^{* *}$ & $0.80^{* *}$ \\
Hot carcass weight & $0.72^{* *}$ & $0.67^{* *}$ & $0.77^{* *}$ \\
Trimmed meat in HCW, \% & -0.56 & $-0.94^{* *}$ & -0.43 \\
Dissected fat, kg & 0.34 & $0.76^{*}$ & 0.51 \\
Total non-carcass fat, $\mathbf{~ k g}$ & 0.26 & 0.10 & 0.42 \\
Total fat store, $\mathbf{k g}$ & $0.78^{* *}$ & $0.95^{* *}$ & $0.91^{* *}$ \\
Total body fat, kg & 0.50 & $0.90^{* *}$ & 0.62 \\
\hline$* \mathrm{P}<0.05, * * \mathrm{P}<0.01$ & & &
\end{tabular}

$* \mathrm{P}<0.05, * * \mathrm{P}<0.01$ 


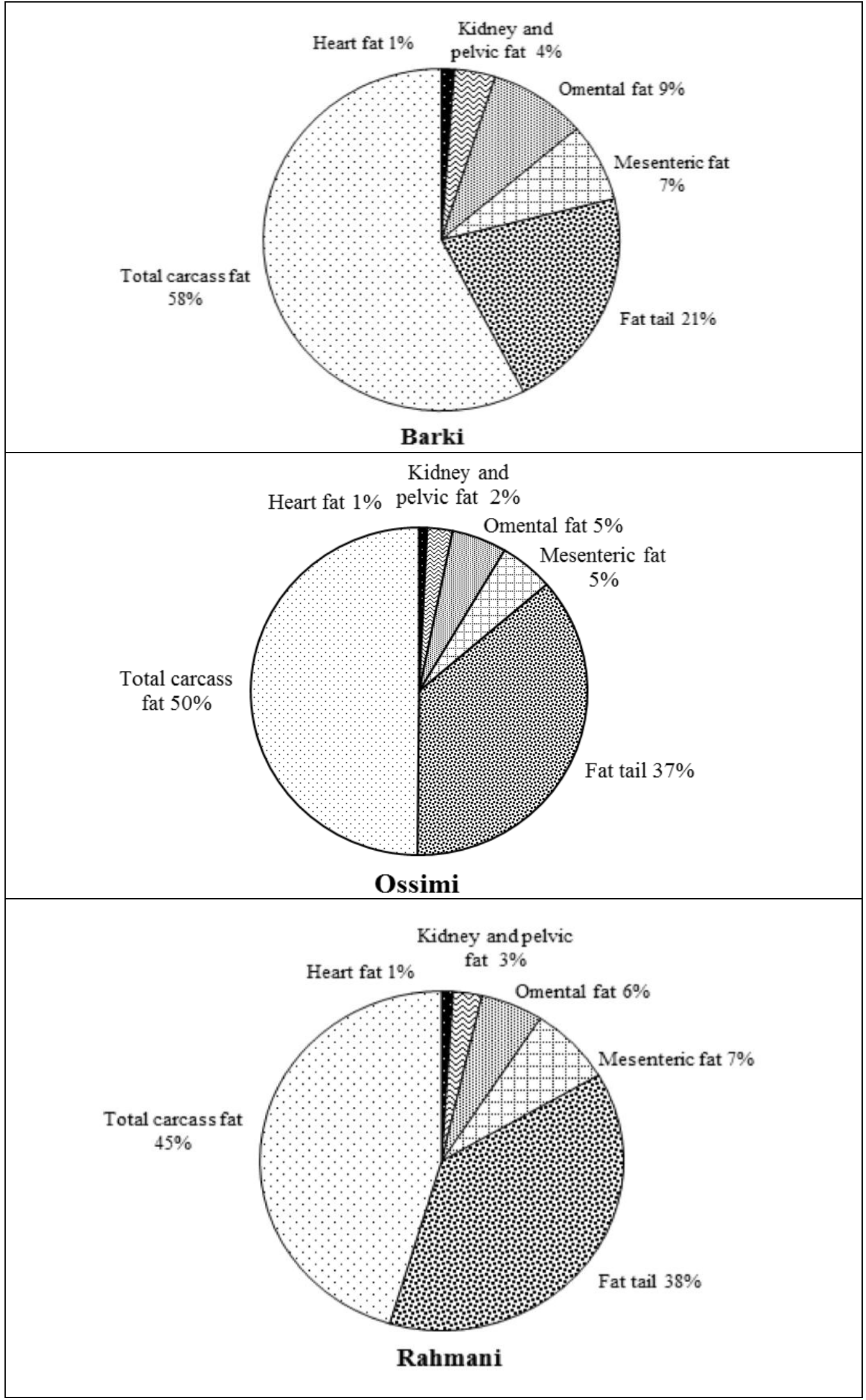

Fig. 2. Carcass and non-carcass fat distribution of Barki, Ossimi and Rahmani ram lambs. 
Prediction equations of tail, dissected carcass and total body fat weight from in vivo fat tail dimensions

Table (5) presents prediction equations of fat tail weight of Barki, Ossimi and Rahmani lambs from in vivo fat tail dimensions. In Ossimi lambs, two fat tail measurements (LFTC and LFTT) were included in the model. This equation represented $90 \%$ and $94 \%$, respectively of the variation in fat tail weight of Ossimi ram lambs (Table 5). In the meantime, UFTC alone contributed for 79 and $86 \%$ of the variation in fat tail weight of both Barki and Rahmani ram lambs, respectively (Table 5). This result agrees with the finding of Zamiri and Izadifard (1997) who established prediction equations for fat tail weight using fat-tail dimensions of Mehraban $\left(\mathrm{R}^{2}=0.83\right)$ and Ghezel $\left(\mathrm{R}^{2}=0.69\right)$ sheep. Similarly, Atti and Ben Hamouda (2004) and Yardimci et al. (2008) established regression equation to estimate tail fat weight based on tail dimensions $\left(\mathrm{R}^{2}=0.75\right)$ for Barbarian lambs and $\left(\mathrm{R}^{2}=0.81\right)$ in Akkaraman sheep, respectively. Safdarian et al. (2008) as well, found that the best equation for predicting fat tail weight (FTW) was attained when upper and lower fat tail circumferences (UFTC and LFTC) accounted for $85 \%$ of the variation in fat tail weight (FTW) of Torki-Ghashghaii ram lambs and such equations might be useful for prediction of the FTW for use in breeding programs. Similarly, Talebi and Vatankhah (2011) used lower fat tail circumference (LFTC) to predict fat tail weight of Lori-Bakhtiari sheep with $\mathrm{R}^{2}=76 \%$. The authors also indicated that, the accuracy of equation increased with using lower fat tail width, fat tail length and lower fat tail circumference $\left(\mathrm{R}^{2}=0.82\right)$.

In the prediction of dissected carcass fat and total body fat weight of Ossimi ram lambs, only LFTT was included in the model (Tables 6 and 7). Coefficient of determination $\left(\mathrm{R}^{2}\right)$ was 73 and $90 \%$, respectively (Tables 6 and 7).

Five variables were included to predict dissected carcass fat weight of Rahmani ram lambs. The first variable was LFTW, which explained $50 \%$ of the variation in dissected carcass fat weight (Table 6). The remaining variables were FTL, LFTC, UFTW and LFTT with accuracy of $68 \%, 91 \%, 98 \%$ and $100 \%$, respectively (Table 6). Whereas, only LFTW is the parameter remaining in the equation to predict total body fat in Rahmani carcasses $\left(\mathrm{R}^{2}=0.73\right)$ (Table 7). Similar situation was observed by (Atti and Ben Hamouda, 2004) who reported that optimum equation for predicting total carcass fat and body fat of Barbarine sheep was attained when tail parameter as independent variables, were entered in the equation $\left(R^{2}=0.69\right)$.

The determination coefficient $\left(\mathrm{R}^{2}\right)$ of prediction equation of dissected carcass fat and total body fat weight of Barki ram lambs were 0.97 and 0.996, respectively (Tables 6 and 7). Although, accuracy was high, but insignificant equations were obtained. It is worthy to note that all measurements used to predict fat tail weight of ram lambs had positive regression coefficients indicating that fat tail weight of ram lambs increased as those measurements increased.

There is general agreement that fat-tail measurements can be made easily and repeatedly on live animals, and could be used as a measure of tail weight with high accuracy in breeding programs and made it possible to repeatedly assess the fattening as well as growth (Zamiri and Izadifard, 1997; Ermias and Rege, 2003; Atti and Ben Hamouda, 2004, Safdarian et al., 2008 Yardimci et al., 2008, Farahani et al., 2010 and Talebi and Vatankhah, 2011).

\section{CONCLUSION}

Fat tail measurements can be used to predict fat weight of tail and carcass in ram lambs. In this context, upper fat tail circumference of Barki and Rahmani ram lambs was the significant variable for predicting fat tail weight. Moreover, lower fat tail circumference and lower fat tail thickness could be included to predict fat tail weight of Ossimi ram lambs.

Table 5. Prediction equations for calculating fat tail weight $(\mathrm{g})$ ( $Y$ ) from in vivo fat tail dimension (cm) (independent variables) of Egyptian ram lambs.

\begin{tabular}{|c|c|c|c|c|c|}
\hline Breed & Steps & Variables & Sig. & $\mathbf{R}^{2}$ & S.E. \\
\hline $\begin{array}{l}\text { Barki: } \\
\text { Equation }=-1884.20+91.24 \text { UFTC }(\mathrm{cm})\end{array}$ & 1 & UFTC & $* *$ & 0.79 & 13.14 \\
\hline Ossimi : & $\begin{array}{l}1 \\
2\end{array}$ & $\begin{array}{l}\text { LFTC } \\
\text { LFTT }\end{array}$ & $\begin{array}{l}* * \\
*\end{array}$ & $\begin{array}{l}0.90 \\
0.94\end{array}$ & $\begin{array}{c}14.42 \\
107.02\end{array}$ \\
\hline Equation $=-3632.82+88.97 \mathrm{LFTC}+309.1$ & & & & & \\
\hline $\begin{array}{l}\text { Rahmani }: \\
\text { Equation }=-2521.12+118.51 \text { UFTC }(\mathrm{cm})\end{array}$ & 1 & UFTC & $* *$ & 0.86 & 13.18 \\
\hline
\end{tabular}


Table 6. Prediction equations for calculating dissected carcass fat $(\mathrm{kg})(Y)$ from in vivo fat tail dimension (cm) (independent variables) of Egyptian ram lambs.

\begin{tabular}{lcccccc}
\hline Breed & Steps & Variables & Sig. & R $^{2}$ & S.E. \\
\hline Barki: & 1 & UFTW & ns & 0.23 & 0.11 \\
& 2 & UFTC & ns & 0.43 & 0.12 \\
& 3 & LFTW & ns & 0.58 & 0.13 \\
& 4 & UFTT & ns & 0.69 & 0.25 \\
& 5 & LFTT & ns & 0.97 & 0.41
\end{tabular}

Equation $=-0.61-0.17$ UFTW -0.48 LFTW +0.48 UFTC +0.81 UFTT -1.16 LFTT $(\mathrm{cm})$

Ossimi :

$1 \quad$ LFTT

** $\quad 0.73$

0.26

Equation $=-2.58+1.03$ LFTT $(\mathrm{cm})$

Rahmani :

$\begin{array}{lllll}1 & \text { LFTW } & * * & 0.50 & 0.002 \\ 2 & \text { FTL } & * * & 0.68 & 0.001 \\ 3 & \text { LFTC } & * * & 0.91 & 0.001 \\ 4 & \text { UFTW } & * * & 0.98 & 0.003 \\ 5 & \text { LFTT } & * & 1.00 & 0.004\end{array}$

Equation $=-5.29+0.32$ FTL -0.36 UFTW + 0.59 LFTW - 0.10 LFTC -0.24 LFTT $(\mathrm{cm})$

UFTC: upper fat tail circumference, LFTC: lower fat tail circumference, LFTT: lower fat tail thickness, UFTT: Upper fat tail thickness, UFTW: upper fat tail width, LFTW: lower fat tail width, FTL, fat tail length, $R^{2}$ : determination coefficient, Sig.: significance, ${ }^{*} \mathrm{P}<0.05, * * \mathrm{P}<0.01$, S.E.: standard error.

Table 7. Prediction equations for calculating total body fat $(\mathrm{kg})$ ( $Y$ ) from in vivo fat tail dimension (independent variables) of Egyptian ram lambs.

\begin{tabular}{lcccccc}
\hline Breed & Steps & Variables & Sig. & R $^{2}$ & S.E. \\
\hline Barki: & 1 & UFTT & ns & 0.37 & 0.14 \\
& 2 & UFTW & ns & 0.59 & 0.08 \\
& 3 & UFTC & ns & 0.68 & 0.04 \\
& 4 & LFTC & ns & 0.78 & 0.07 \\
& 5 & FTL & ns & 0.996 & 0.06
\end{tabular}

Equation $=10.07+0.50$ FTL -0.94 UFTW + 0.40 UFTC -0.67 LFTC +1.58 UFTT $(\mathrm{cm})$

\begin{tabular}{|c|c|c|c|c|c|}
\hline $\begin{array}{l}\text { Ossimi : } \\
\text { Equation }=-6.80+2.34 \text { LFTT }(\mathrm{cm})\end{array}$ & 1 & LFTT & $* *$ & 0.90 & 0.32 \\
\hline $\begin{array}{l}\text { Rahmani : } \\
\text { Equation }=-4.80+0.47 \text { LFTW }(\mathrm{cm})\end{array}$ & 1 & LFTW & $*$ & 0.73 & 0.13 \\
\hline
\end{tabular}

UFTC: upper fat tail circumference, LFTC: lower fat tail circumference, LFTT: lower fat tail thickness, UFTT: Upper fat tail thickness, UFTW: upper fat tail width, LFTW: lower fat tail width, FTL, fat tail length, $R^{2}$ : determination coefficient, Sig.: significance, $* \mathrm{P}<0.05, * * \mathrm{P}<0.01$, S.E.: standard error.

\section{REFERENCES}

Abdel-Moneim, A.Y., 2009. Body and carcass characteristics of Ossimi, Barki and Rahmani ram lambs raised under intensive production system. Egypt. J. Sheep and Goat Sci., 4(2):1-16.

Ali, M.M.M., 2007. Growth curve and carcass characteristics of Ossimi and Rahmani lambs during the first year of age. M.Sc. Thesis Fac. Agric., Cairo Univ., Cairo, Egypt.

Alkass, J.E., N.H. Rashid, M. Ali Ishak and H. Talib, 1985. The combined effects of docking and castration on growth rate and carcass characteristics of Awassi lambs. World Rev. Anim. Prod., 21:49-52.

Atti, N. and M. Ben Hamouda, 2004. Relationships among carcass composition and tail measurements in fat-tailed Barbarian sheep. Small Ruminant Res., 53:151-155.

Awadalla, I.M., M.I. Mohamed, M.A.M. Ibrahim and Amal, K. El-Asheeri, 1997. Efficiency of using groundnut hay in ration of Rahmani lambs. Egypt. J. Anim . Prod., 34(2):125-134. 
Awgichew, K., 2000. Comparative performance evaluation of Horro and Menz sheep of Ethiopia under grazing and intensive feeding conditions. Ph.D. Thesis, Humboldt-Universität zu, Berlin, Germany.

Ben Hamouda, M. and N. Atti, 2011. Comparison of growth curves of lamb fat tail measurements and their relationship with body weight in Barbarian sheep. Small Ruminant Res., 95:120-127.

Berg, R. T. and L. E. Walters, 1983. The meat animal: Changes and challenges. J. Anim. Sci., 57(2):133-146.

Burke, J.M. and J.K. Apple, 2007. Growth performance and carcass traits of forage - fed hair sheep wethers. Small Rumin. Res., 67:264-270.

Butler-Hogg, B. W., M. A. Francombe and E. Dransfield, 1984. Carcass and meat quality of ram and ewe lambs. Anim. Prod., 39:107-113.

Diaz, M.T.; V. Cañeque; S.Lauzurica; S. Velasco; F. Ruiz de Huidobro and C. Pérez, 2004. Prediction of suckling lamb carcass composition from objective and subjective carcass measurements. Meat Sci., 66: 895-902.

El-Asheeri, A.k., Y.M. Hafez, M.A. Ibrahim, M.M. Ali and A.H. Barkawi, 2006. Growth performance of Rahmani and Ossimi lamb breeds from birth to 12 months of age. In the 13th conference of the Egyptian Society of Animal Production, Cairo, Egypt. Egypt. J. Anim. Prod., 43 (Suppl. Issue):31-42.

El-Karim, A.I.A. and J.B. Owen, 1987. Post-weaning growth performance, carcass characteristics and preliminary heritability estimate for some carcass traits of two types of Sudan Desert sheep on intensive feeding. J. agric. Sci. (Camb.), 109(3):531-538.

El-Shahat, A.A., A.Z. EL-Basiony, G.A. Abd ElRahman and H.M. Aly, 1986. Effect of interaction between breed and plane of nutrition on sheep carcass tissues. Egypt. J. Anim. Prod., 26(2):129-135.

Ermias, E. and J.E.O. Rege, 2003. Characteristics of live animal allometric measurements associated with body fat in fat-tailed sheep. Livest. Prod. Sci., 81:271-281.

Farahani, K.A.H., H. Moradi Shahrbabak, M. Moradi Shahrbabak and H. Mehrabani Yeganeh, 2010. Relationship of fat-tail and body measurements with some economic important traits in fat-tail Makoei breed of Iranian sheep. Afr. J. Biotechnol., 9(36):5989-5992

Farid, A., J. Izadifard, M. A. Edris and M. Makarechian, 1983. Meat from culled old ewes of two fat-tailed Iranian breeds. 2. Meat, subcutaneous fat, and bone in the wholesale cuts. Iran Agric. Res., 2:93-114.

Galal, E.S.E.; Y.S.Ghanem; M.A. Farid; M.H. Fahmy and A.E.M. Seoudy (1975). Carcass traits and feed-lot performance of Barki, Merino and
Awassi breeds of sheep and some of their crosses. Egypt. J. Anim . Prod., 15 (1) : 33-46.

Gokdal, O., T. Aygun, M. Bingoal and F. karakus, 2003. The effect of docking on performance and carcass characteristics of male Karakas lambs. South African J. Anim. Sci., 33(3):185-192.

Hassan, H.A. and F.M.R. EL-Feel, 1991. The effect of breed, level of feeding, age and slughter weight on performance and carcass traits of lambs. Egypt. J. Anim. Prod., 28(2):157-168.

Hassan, A.H., S.T.M. Fahmy, M.T. Mousa and A.I.A. Suliman, 1996. The effect of crossbreeding between Chios and Ossimi sheep on growth performance and carcass characteristics of male lambs. In the 9th conference of the Egyptian Society of Animal Production, Shebin El-Kom, Menoufyia, Egypt. Egypt. J. Anim. Prod., 33 (Suppl. Issue):61-70.

Kadak, R., 1983. Comparison of the fattenning performance and carcass characteristics of male Akkaraman, Morkaraman ve Ivesi lambs. Ph.D. Thesis, Frrat Univ. Vet. Fac., Elazig, Turkey.

Marshall, W.; M. Collantes; A. Corchado; J.A. Bertot; F. Uña; V. Torres and L. Sarduy, 2005. Prediction of the carcass, tissue composition and regional traits in Pelibuey sheep supplemented with poultry litter and soybean meal. Cuban J. Agric. Sci.,39(1): 33-40.

Mowafy, M.A., 1968. Comparative studies on the meat quality of the local and imported breeds. M.Sc. Thesis, Fac. Agric., Ain Shams Univ., Cairo, Egypt.

National Research Council (NRC), 1985. Nutrient Requirements of Sheep (6th revised ed.). Washington, DC: National Academy of Science.

Orr, R.M., 1982. Animal production. Animal physiology. In: "Haaley, R.T. (ed.) The Agricultural Note Book 17th edition". Butterworths and Co. Ltd., London. pp. 305-318.

Ozcan L., O. Gursory, E. Pekel and O. Torun, 1994. Growth performances and carcass merits of Turkish Awassi sheep. In: Galal E.S.E. and Gursory O. (Eds.), Strategies for the development of Fat-Tail Sheep in the Near East. Wageningen press, pp. 57-63

Pérez, P., M. Maino, M.S. Morales, C. Köbrich, C. Bardon and J. Pokniak, 2007. Gender and slaughter weight effects on carcass quality traits of suckling lambs from four different genotypes. Small Ruminant. Res., 70:124-130.

Ruvuna, F., J. F. Taylor, M. Okeyo, M. Wanyoike and C. Ahuya, 1992. Effects of breed and castration on slaughter weight and carcass composition of goats. Small Ruminant Res. 7:175183.

Safdarian, M., M.J. Zamiri, M. Hashemi and H. Noorolahi, 2008. Relationships of fat-tail dimensions with fat-tail weight and carcass characteristics at different slaughter weights of Torki-Ghashghaii sheep. Meat Sci., 80:686-689. 
SAS, 2004. SAS User's Guide: Statistics. SAS Inst. Inc., Cary, NC., USA.

Seker, I. and S. Kul, 2001. The relationships between live body weight, body measurements and some carcass characteristics at different ages of Awassi yearling ram lambs. Saglk Bilimleri Dergisi, Firat Universitesi, 15(2):353-360.

Talebi, M.A. and M. Vatankhah, 2011. Estimation of fat-tail weight by external fat-tail dimensions in Lori-Bakhtiari sheep. J. Agric. Sci. Technol., 1:1241-1244

Vatankhah, M. and M.A. Talebi, 2008. Genetic parameters of body weight and fat-tail measurements in lambs. Small Ruminant Res., 75:1-6.

Yardımcı, M., E. Hesna Şahin, İ.S. Çetingül, İ. Bayram, K. Altunbaş and E. Şengör, 2008. Estimation of carcass composition and fat depots by means of subcutaneous adipocyte area and body and tail measurements in fat-tailed Akkaraman lambs. S. Afr. J. Anim. Sci., 38(4):282-289.

Zamiri, M.J. and J. Izadifard, 1997. Relationships of fat-tail weight with fat-tail measurements and carcass characteristics of Mehraban and Ghezel rams. Small Ruminant Res., 26:261-266.

\footnotetext{
إستخدام مقاييس الذيل للتنبؤ بوزن دهن الذيل ودهن الذبيحة في سلالات الحوالى المصرية رانيا عجمي، احمد يحيى عبد المنعم، ممدوح سيد عبد الله، ابراهيم ابراهيم عبد المجيد، جلال الدين عشماوي

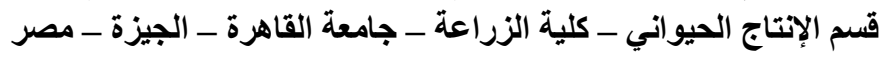

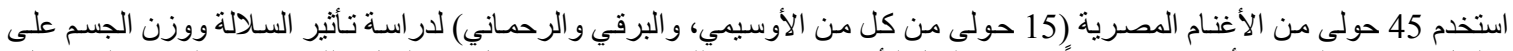

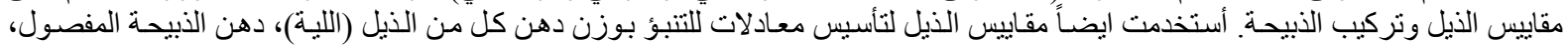

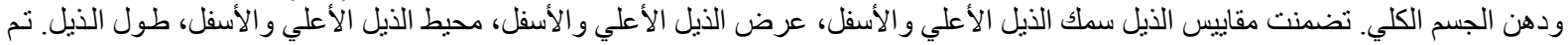

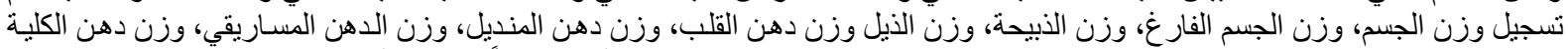

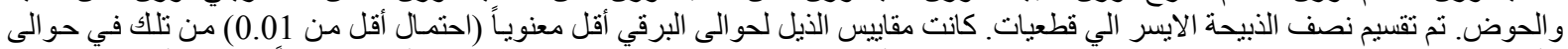

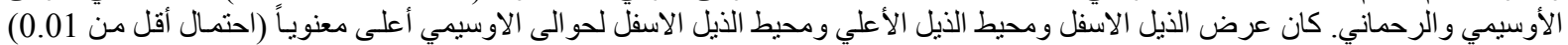

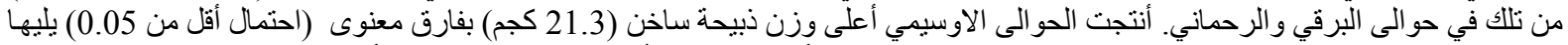

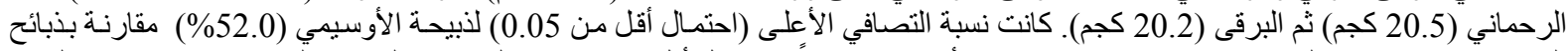

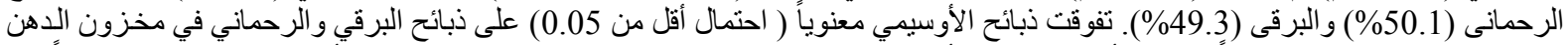

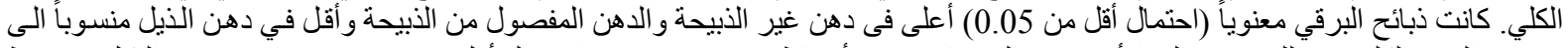

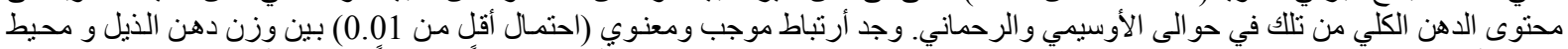

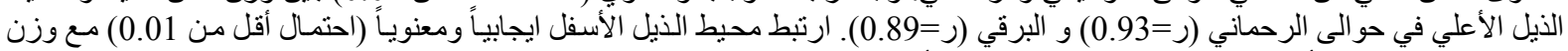

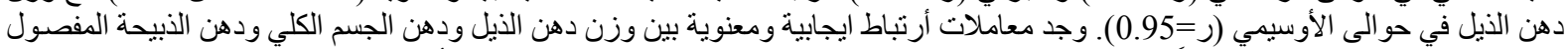

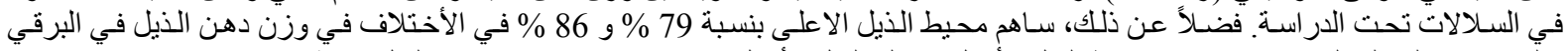

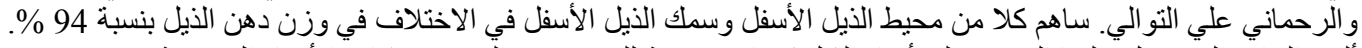
ألقت النتائج المتحصل عليها الضوء على أبعاد الذيل كمقاييس دقيقة للتنبؤ بوزن الأدهن في ذبائح الأغنام المصرية.
} 